\title{
Southern Perú coseismic subsidence: 23 June 2001 8.4-Mw earthquake
}

\author{
L. Ocola \\ Instituto Geofísico del Perú, Sector Educación, Calle Badajoz 169, Lima 3, Perú \\ Received: 1 June 2007 - Revised: 20 August 2007 - Accepted: 24 August 2007 - Published: 2 January 2008
}

\begin{abstract}
The 23-June-2001 8.4-Mw magnitude earthquake partially filled the 1868-seismic-gap in southern Perú. This earthquake produced a thrust faulting dislocation with a rupture that started at about $\sim 200 \mathrm{~km} \mathrm{SE}$ from the 1996's Nazca earthquake epicenter, and stopped near Ilo, at about $300 \mathrm{~km}$ from the epicenter, near a positive gravity anomaly offshore Ilo. The 23-June-2001-earthquake dislocation zone is under the Arequipa sedimentary Basin. Pre- and post-seismic GPS measurements at Camaná and Ilo at SIRGAS-GPS points (SIRGAS: Sistema de Referencia Geocéntrico para América del Sur) and the average sea level pre- and post-seismic event at Mollendo tide gauge provide evidence of a regional subsidence of southern Perú, with $84 \mathrm{~cm}$ at Camaná, $16 \mathrm{~cm}$ at Ilo, and $15 \mathrm{~cm}$ at Mollendo. Field surveys post earthquake document significant subsidence in Camaná resort beaches. Results of a simple dislocation modelling of 23-June-2001 earthquake agree reasonably well with the observed data. However, the coseismic subsidence of southern Perú is at variance with the regional uplift of southern Perú based on Neotectonic studies. This fact, suggests that, in recent geological times, the magnitude of the secular uplift due to tectonic plate converge has been larger than the coseismic deformation recovery.
\end{abstract}

\section{Introduction}

On 23 June 2001, an 8.4-Mw-magnitude earthquake struck Southern Perú causing severe damage on the built and natural environments. The Geophysical Institute of Perú (IGP) locates the hypocenter at $16.462^{\circ} \pm 3.9 \mathrm{~km}$ south latitude, $73.936^{\circ} \pm 2.5 \mathrm{~km}$ west longitude and $30.4 \mathrm{~km} \pm 9.5 \mathrm{~km}$ depth using data from the IGP's local seismic networks. The maximum severity of ground shaking was $7^{-}$MSK (Tavera et al., 2006). The earthquake was produced by a thrust faulting mechanism with a minor sinistral strike displacement component (e.g., Harvard Centroid Moment Tensor solution,

Correspondence to: L. Ocola

(geo_gps@geo.igp.gob.pe)
NEIC, 2005; Tavera et al., 2002). According to Harvard's focal mechanism solution, one of the nodal planes has $310^{\circ}$ strike and $18^{\circ}$ dip, and $63^{\circ}$ slip angle. The other nodal plane has strike, dip and slip angle: $159^{\circ}, 74^{\circ}$ and $98^{\circ}$, respectively, the centroid is located at Lat. $17.28^{\circ} \mathrm{S}$, Lon. $72.71^{\circ} \mathrm{W}$, and $29.6 \mathrm{~km}$ depth (NEIC, 2005) (Fig. 1).

\section{Geophysical setting}

The bulk of the geophysical-oceanographic systematic data, and knowledge of the Nazca Plate and neighbouring areas shallow structure come form the Nazca Plate Project of the International Decade of Ocean Exploration Program, carried out by the Hawaii Institute of Geophysics and the Oregon State University with the participation and collaboration of several South American scientific institutions, like the Institute of Geophysics of Perú (Kulm et al., 1981). In this section, some of the relevant information related to the 23-June2001-earthquake source region is summarized.

The 23-June-2001-earthquake is located SE of the Nazca Ridge. The epicenter is east of the Perú-Chile trench deepest part $(>7000 \mathrm{~m})$, offshore of southern Perú. The spatial dimension of the dislocation rupture, as estimated from the aftershock distribution and source modelling, is under the Arequipa fore-arc sedimentary basin. The earthquake epicenter is located near the NW basin's boundary and the rupture stopped close to its SE boundary, near Ilo, in the transition zone of Arequipa-Arica Quaternary sedimentary basins.

According to Johnson and Ness (1981), the Arequipa Basin (Mollendo basin of Couch and Whitsett, 1981) lies from $16^{\circ}$ to $18^{\circ} \mathrm{S}$ latitude along the southern Perú coastline, under $100-1500 \mathrm{~m}$ water depth. It is a prominent elongated feature of regional size that lies "landward of a tectonically formed upper-slope break" (Johnson and Ness, 1981, p. 542). It has a broad synclinal axis, and occasionally exhibits minor faulting. A seismic reflection profile, $100 \mathrm{~km} \mathrm{NW}$ of Mollendo, "reveals a continental slope with very irregular topography that extends from the trench nearly to the coastline. The topmost sediments appear disturbed and the general

Published by Copernicus Publications on behalf of the European Geosciences Union. 


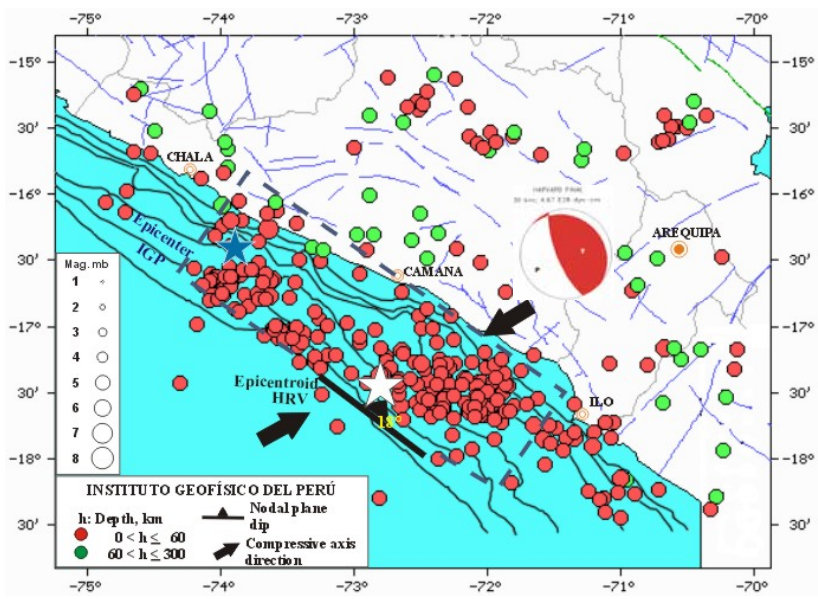

Fig. 1. June-23-2001-earthquake approximate rupture area (rectangle) and four years of $>4.4 \mathrm{mb}$ magnitude earthquakes in the rupture and neighbouring areas. White star: Epicentroid.

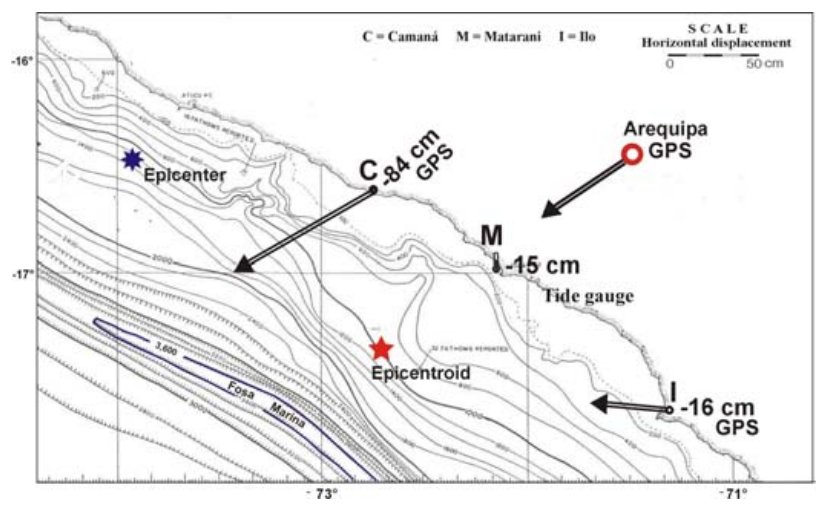

Fig. 2. Chase (1968) bathymetry, Subsidence of Camaná (C) and Ilo (I) determined from GPS data, Matarani (M) tide-gauge subsidence determined from tide-gauge analog records (Koshimura and Sato, 2005). Arrows show GPS horizontal displacement vectors.

shape of the slope suggest block faulting on a large scale" (Couch and Whitsett, 1981), with seaward convergence of sedimentary reflectors against the outer structural high. Johnson and Ness (1981, p. 538-539) mentioned "Thinning of layers towards the outward structural high is evidence for either the gradual uplift of the slope break or the down warping of the basin axis between episodic tilting or uplift events". The epicenter and epicentroid of the 23-June-2001-Arequipa earthquake and the bathymetry from Chase (1968) are shown in Fig. 2.

Couch and Whitsett (1981) free-air anomaly map, complemented with Coulbourn's (1981) data, is shown in Fig. 3. The latter data were adjusted for an apparent spatial shift and somehow smoothed to fit contour lines. This figure shows the free-air gravity anomalies of the Nazca Ridge: Extreme value $\sim+20 \mathrm{mGal}$ near the trench, the Perú-Chile

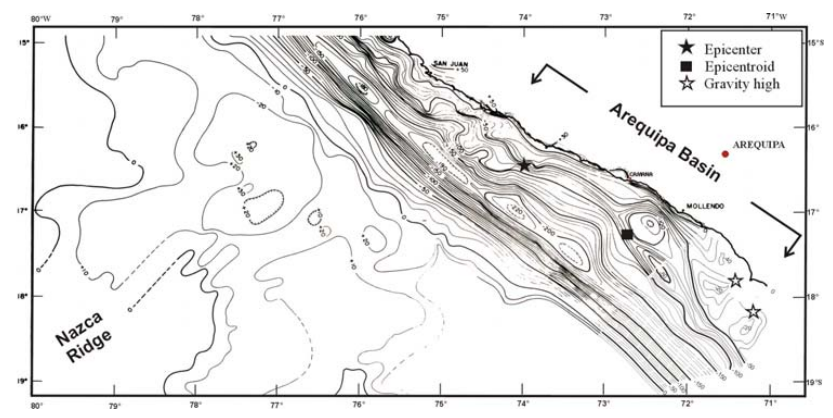

Fig. 3. Free-Air gravity anomalies offshore San Juan (Nazca)Arica, after combing and adjusting Couch and Whitsett (1981) Fig. 3 and Coulbourn (1981) Fig. 3 maps. White star: Gravity high (Arequipa-Arica basins transition zone). Black square: Epicentroid.

trench: Extreme anomaly $-220 \mathrm{mGal}$, and the anomalies on the continental shelf. There is a well-developed negative free-air gravity anomaly offshore Mollendo, with extreme value of $-110 \mathrm{mGal}$. The gravity maxima, indicated in Fig. 2 by stars, were identified by Coulbourn (1981) in the magnetic-residual and gravity maps. Couch and Whitsett [1981, p. 571-572] remark the "absence of anomaly contours coincident with the bathymetric contours that outline the Nazca Ridge.", i.e., the Nazca Ridge is a topographic feature isostatically compensated.

The upper crustal structure under the Arequipa (Mollendo) Basin, based on a seismic reflection profile and gravity data, shows a sedimentary basin of $\sim 60 \mathrm{~km}$ wide in the $\mathrm{N} 46^{\circ} \mathrm{E}$ direction near Mollendo, $1.4 \mathrm{~km}$ thick sediments with a density of $1.8 \mathrm{~g} / \mathrm{cm}^{3}$, overlying Cenozoic-Mesozoic rocks of $2.2 \mathrm{~g} / \mathrm{cm}^{3}$ and $5.0 \mathrm{~km}$ extreme thickness resting on $2.5 \mathrm{~g} / \mathrm{cm}^{3}$ - Precambrian/Mesozoic basement from the trench nearly to the coastline. The estimated propagation velocity of seismic waves in the shallow sediments was assumed to be $1.8 \mathrm{~km} / \mathrm{s}$. The topography of the CenozoicMesozoic/Mesozoic-Precambrian interface is not regular. The maximum and minimum depths of this interface, under the Arequipa basin, are 5.2- and $3.5-\mathrm{km}$ bmsl, respectively. Its average inclination towards the trench is $\sim 2.2^{\circ}$, with a 2 $\mathrm{km}$ depression about midway of the continental slope. The crustal model suggests, "that differential motion in the blocks of basement rocks has deformed the overlying sediments" (Couch and Whitsett, 1981, p. 379).

Couch and Whitsett (1981) report that the "axis of the gravity anomaly minima is located 5- to $15-\mathrm{km}$ landward of the bathymetric axis of the trench, north and south of the ridge, and coincides with the axis near the ridge" (Nazca Ridge). Probably, modern light subducted sediments under the lower continental slope might produce the negative gravity anomaly axis shift toward the continent.

Coulbourn's (1981) magnetic anomalies map shows long wavelength anomalies, with tendency to be parallel to the trench, along the shelf and continental slope south of the 
$17^{\circ} \mathrm{S}$ latitude. These anomalies are interrupted, in the shelf, by short wavelenght anomalies with contours lines perpendicular to general pattern of the magnetic anomalies in the Arequipa-Arica basins. These short wavelength anomalies mark the boundary between these sedimentary basins (Fig. 2).

\section{Continental coseismic subsidence}

The GPS program to monitor crustal deformation and displacement was initiated by IGP, under the auspices of USA institutions, through the "South America Nazca Plate Project" (SNAPP) in 1994, by recording GPS data on discrete monuments in Perú. The first reoccupation of the GPS monuments was done in 1996. Norabuena et al. (1998) published the rate of deformation of southern Perú-Bolivia. Horizontal deformation data did not show any anomaly. However, the analysis of the rate of deformation on the vertical component showed a negative anomaly that nucleated onshore of the 1868 seismic gap (Ocola, 2001). On the other hand, preliminary results of the coseismic displacements for the 12-November-1996 Nazca earthquake showed a significant rebound and clockwise rotation with respect to the secular crustal deformation at the GPS points in the epicentral area of this earthquake (Norabuena and Ocola, 2000).

The South, Central and North American countries, through the SIRGAS joint project, established and maintain a unique "geocentric reference frame for practical and scientific use" (Fortes et al., 2007). SIRGAS is an acronym of the initial name of the project: "Sistema de Referencia Geocéntrico para América del Sur" (South American Geodetic Reference System). The National Geographic Institute (IGN), the official national geodetic agency, established, as part of the National Geodetic Network, one SIRGAS-GPS point at Camaná City and another one at Ilo City in January, 1998. Camaná- and Ilo-GPS sites are at $137 \mathrm{~km}$ ESE and $314 \mathrm{~km}$ SE of IGP's January-23-2001-earthquake epicenter, respectively. The HRV epicentroid distances and directions to $\mathrm{Ca}$ maná and Ilo points are: $72 \mathrm{~km} \mathrm{~N}$ and $155 \mathrm{~km} \mathrm{ESE}$, respectively.

In July 2001, we reoccupied Camaná and Ilo SIRGASGPS points with Leica GPS double frequency receivers, for five continuous days, and sampling GPS data every $30 \mathrm{~s}$. The field GPS data were processed with GAMIT/GLOBK software. The computed displacements are summarized in Table 1 for Camaná point, and Table 2 for Ilo point.

These results show that at Camaná, the continental block was horizontally displaced $95 \mathrm{~cm} \pm 0.6 \mathrm{~cm}$ in the $\mathrm{N} 244^{\circ} \mathrm{E}$ direction and subsided $84 \mathrm{~cm}$ (Table 1, Fig. 2), and Ilo was displaced $41 \mathrm{~cm} \pm 0.5 \mathrm{~cm}$ in the $\mathrm{N} 279^{\circ} \mathrm{E}$ direction and subsided $16 \mathrm{~cm}$ (Table 2), i.e., Camaná moved to the south west and Ilo to the west-northwest (Fig. 2). A simple dislocation simulation, using Harvard's focal mechanism and Mansinha and Smylie's (1971) algorithms, gives the following theo-
Table 1. Episodic displacement at SIRGAS-GPS Camaná point WGS84 Elipsoid. 23-June-2001 Arequipa earthquake.

\begin{tabular}{|c|c|c|c|c|c|c|c|}
\hline \multirow{2}{*}{$\begin{array}{c}\text { AGEN } \\
\text { CY }\end{array}$} & \multirow[t]{2}{*}{$\begin{array}{l}\text { MONTH } \\
\text { YEAR }\end{array}$} & \multicolumn{2}{|c|}{$\begin{array}{c}\text { POSITION } \\
\text { LAT / LON / ELEV }\end{array}$} & \multicolumn{3}{|c|}{$\begin{array}{c}\text { DISPLACEMENT } \\
1998 \text { - } 2001 \\
\end{array}$} & \multirow{2}{*}{$\begin{array}{c}\text { GPS } \\
\text { RECIEVER } \\
\text { SOFTWARE }\end{array}$} \\
\hline & & VALUE & \begin{tabular}{|c|} 
ERROR \\
$\mathrm{mm}$
\end{tabular} & $\begin{array}{c}\text { DXi } \\
\text { m }\end{array}$ & \begin{tabular}{|c|}
$\begin{array}{c}\text { Horiz. } \\
\text { m }\end{array}$ \\
\end{tabular} & $\begin{array}{c}\text { Total } \\
\text { m }\end{array}$ & \\
\hline \multirow{3}{*}{ IGN } & JANUARY & $\begin{array}{c}16^{\circ} 37^{\prime} \\
29.17723^{\prime \prime} \mathrm{S}\end{array}$ & & & & & \multirow{3}{*}{ TRIMBLE } \\
\hline & \multirow[t]{2}{*}{1998} & $\begin{array}{c}72^{\circ} 42^{\prime} \\
41.32592^{\prime \prime} \mathrm{W}\end{array}$ & & & & & \\
\hline & & $41.5662 \mathrm{~m}$ & & & & & \\
\hline \multirow{3}{*}{ IGP } & \multirow{3}{*}{$\begin{array}{l}\text { JULY } \\
2001\end{array}$} & $16.624775363^{\circ} \mathrm{S}$ & 2.0 & -0.423 & & & \multirow{3}{*}{ GAMIT/GLOBK } \\
\hline & & $72.711487354^{\circ} \mathrm{W}$ & 5.1 & -0.851 & 0.950 & 1.268 & \\
\hline & & $40.72684 \mathrm{~m}$ & 10 & -0.839 & & & \\
\hline
\end{tabular}

Table 2. Episodic displacement at SIRGAS-GPS Ilo point. WGS84 Ellipsoid. 23-June-2001 Arequipa earthquake.

\begin{tabular}{|c|c|c|c|c|c|c|c|}
\hline \multirow{2}{*}{$\begin{array}{l}\text { AGE } \\
\text { NCY }\end{array}$} & \multirow[t]{2}{*}{$\begin{array}{c}\text { MONTH } \\
\text { YEAR }\end{array}$} & \multicolumn{2}{|c|}{$\begin{array}{c}\text { POSITION } \\
\text { LAT / LON / ELEV }\end{array}$} & \multicolumn{3}{|c|}{$\begin{array}{c}\text { DISPLACEMENT } \\
1998 \text { - } 2001\end{array}$} & \multirow{2}{*}{$\begin{array}{c}\text { GPS } \\
\text { RECEIVER } \\
\text { SOFTWARE }\end{array}$} \\
\hline & & VALUE & $\underset{\substack{\text { ERROR } \\
\mathrm{mm}}}{\text {. }}$ & $\underset{\mathrm{m}}{\mathbf{D X i}}$ & Horiz. & \begin{tabular}{|c|} 
Total \\
$\mathrm{m}$
\end{tabular} & \\
\hline \multirow{3}{*}{ IGN } & \multirow{3}{*}{$\begin{array}{c}\text { JANUARY } \\
1998\end{array}$} & $\begin{array}{c}17^{\circ} 38^{\prime} \\
46.76794^{\prime \prime} \mathrm{S}\end{array}$ & & & & & \multirow{3}{*}{ TRIMBLE } \\
\hline & & $\begin{array}{c}71^{\circ} 20^{\prime} \\
42.9616^{\prime \prime} \mathrm{W}\end{array}$ & & & & & \\
\hline & & $46.6745 \mathrm{~m}$ & & & & & \\
\hline \multirow{3}{*}{ IGP } & \multirow{3}{*}{$\begin{array}{l}\text { JULY } \\
2001\end{array}$} & $17.646323773^{\circ} \mathrm{S}$ & 1.9 & +0.068 & & & \multirow{3}{*}{ GAMIT/GLOBK } \\
\hline & & $71.345255563^{\circ} \mathrm{W}$ & 4.9 & -0.409 & 0.415 & 0.446 & \\
\hline & & $46.5115 \mathrm{~m}$ & 9.8 & -0.163 & & & \\
\hline
\end{tabular}

retical subsidence values: $60 \mathrm{~cm}$ at Camaná, $5 \mathrm{~cm}$ at Arequipa CGPS station, and near cero at. Ilo. The Arequipa Continuous GPS (CGPS) recording station, at $\sim 286 \mathrm{~km}$ ESE of IGP's epicenter and $163 \mathrm{~km}$ NE from HRV epicentroid, showed, since 1998, no significant episodic change in the deformation trend on any of the three geocentric coordinates prior to the June-23-2001-earthquake. The coseismic displacement of Arequipa-GPS site, according to Ruegg et al. (2001), was $0.43 \pm 0.05 \mathrm{~m}$ west, $0.27 \pm 0.02 \mathrm{~m}$ south, i.e., $51 \mathrm{~cm}$ total horizontal displacement. The vertical component displacement was "not seen because of the lesser precision of the altimetric determination due to tropospheric perturbations in the electromagnetic propagation of the GPS signal." (Ruegg et al., 2001, p. 674). The Arequipa-GPS-horizontaldisplacement vector has an azimuth $\mathrm{N} 238^{\circ} \mathrm{E}$. The Ilo and the Arequipa horizontal displacement vectors converge near the epicentroid area; however, the Ilo and the Camaná vectors converge farther west, near the Peru-Chile trench axis (Fig. 2).

Based on the Arequipa-CGPS station temporal behavior pre-June-23-earthquake, it is reasonable to assume that displacements determined at the Camaná- and Ilo-GPS stations were produced by the June-23-2001-earthquake as a coseismic displacement. The horizontal displacement of Camaná and Ilo and the subsidence affected the sea level and the shoreline position. 
The Camana and Ilo subsidence is in accord with the $15 \mathrm{~cm}$ subsidence of Matarani tide gauge (mareograph) determined by Koshimura and Sato (2005) from the hourly averages of the Matarani analog record (mareogram) before and after June-23-2001-earthquake. The GPS data and the Matarani tide gauge coseismic subsidence data are shown in Fig. 2.

The continental subsidence in Camaná region along the coastal area can be observed as an apparent sea level rise and shoreline retreat. This fact is evident in the Camaná seashore resort area, e.g., Cerrillos beach , where 200-300 m land remains under water after the earthquake - former Panamito Restaurant and nearby summer huts (GPS WGS84 coordinates: $16^{\circ} 39.52^{\prime} \mathrm{S}$ latitude, $72^{\circ} 38.60^{\prime} \mathrm{W}$ longitude). Sea waves can be observed post-earthquake from the Gallinazos farm (Camaná Delta), they were not possible to be seen before the earthquake.

The observed coastal permanent subsidence produced by the 23-June-2001-earthquake in southern Perú is at variance with the permanent coastal uplift produced by the 12-November-1996 Nazca earthquake (Harvard Centroid: $15.040^{\circ} \mathrm{S}$ latitude, $75.370^{\circ} \mathrm{W}$ longitude, $37.4 \mathrm{~km}$ depth, 7.7 Mw magnitude). Ocola et al. (2006) report a coastal permanent uplift $\sim 70 \mathrm{~cm}$, estimated from the position of the preseismic sea-level mark on coastal cliffs at the epicentral area. The Nazca centroid is located close to the coastal line, and the ruptured block is in a zone where the Nazca Ridge meets the South American continent.

Neotectonic studies of southern Perú showed that the coastal tectonic block southeast of the Nazca Ridge has undergone a secular uplift (Macharé and Leureyro, 1991) during neoctectonic times. This implies that the accumulated interseismic secular coastal uplift is greater than the accumulated episodic coseismic subsidence produced by large earthquakes, like the one of 23-June-2001.

\section{Discussion}

The coincidence of the 23-June-2001-earthquake rupture area surface projection with the Arequipa upper-slope sedimentary basin is extraordinary. The rupture stopped at the transverse gravity and magnetic local-high anomalies near Ilo, just in the seawards extension of the continental Chololo fault system near Ilo. The strike of this fault system is approximately normal to the Perú-Chile trench. This relationship is in accord with the strong correlation between trenchparallel gravity anomalies and location of areas experiencing large coseismic slip reported by Song and Simons (2003).

The 23-June-2001-earthquake filled the NW area of the 1868-seismic gap. This gap has been recognized internationally as a region of high potential for a large magnitude earthquake since the decade of the seventies. In 1978, the International Association for Earthquake Engineering held an International Workshop on Strong Motion Earthquake Instrument Array in Honolulu, Hawaii, and recommended, among other things, that "Earthquake-threatened countries individually and collectively initiate the immediate installation of minimal arrays of 10-20 strong-motion instruments at least at the 28 world-wide sites identified by this workshop" (Iwan, 1978, p. ix); and "A mobile strong-motion instrument array capable of making source mechanism, wave propagation and local effects measurements be established and maintained for deployment immediately following the occurrence of a major earthquake for recording of aftershocks" (Iwan, 1978, p. ix). Among the world's 28 promising locations for the strong-motion arrays were: 1) Ica (Perú), in recognition of a seismic gap after the 1948 earthquake. This gap was filled by the 1996 Nazca Earthquake, 2) Arica (Chile) for the 1868 seismic gap, 3) Perú: Cordillera (Mobile array site) to document shallow continental earthquakes, like 1950 Cusco, 1946 Quiches, 1960 Arequipa, etc. earthquakes (Iwan, 1978). Unfortunately, none of these arrays had been implemented and very valuable data were lost.

One of the last comprehensive seismic potential assessments of the Pacific Ocean rim was done by Nishenko (1985). Due to the lack of information, the level of probabilities of large earthquakes in the following decades ranged from 20-90\%. It depends on the king of probability distribution used to describe the seismic process. The SNAPP results showed no horizontal velocity of deformation anomaly in 1998. However, the vertical component did show an anomaly in land projection of the rupture area of the 23-June-2001 earthquake (Ocola, 2001).

From the point of view of prevention and mitigation of tsunamis disasters, the protective function of the marine barrier against the violence of the tsunami impact was one of the most important observed features of the 23-June-2001earthquake. The barrier prevented the tsunami inundation reach the Camaná City itself, and diminished the violence of the impact of the rushing up tsunami waves in the Camaná Delta Front, the Camaná River and part of the Puchchun farming area, prevented ground erosion, etc. On the other hand, the tsunami impact was very destructive in the Camaná summer resort area at the southeast of the Camaná Delta, where there was no marine barrier. However, due to the coseismic subsidence of the continent, the barrier altitude, with respect to mean sea level, is lower now than it was before the 23-June-2001-earthquake. As a consequence, the Camaná City vulnerability to future tsunamis has been increased; hence the disaster risk potential of the city of $\mathrm{Ca}$ maná due to tsunamis is higher now than it was before the 23-June-2001-earthquake.

The coseismic displacement of Camaná and Ilo SIRGAS monuments documents the need to reoccupy SIRGAS monuments in and around the epicentral area immediately after the occurrence of a moderate-large earthquake, in order to assess changes in the national-geodetic-reference-frame monument's coordinates. However, it is important to recognize that the recovery to the preseismic secular velocity change in the monument's position takes some time. There is no 
experience about how long a time takes the recovery of the pre-seismic steady state of the deformation process. Continuous permanent GPS stations in the epicentral area can provide such key information. Thus, to reduce any postseismic geodetic position determination to the current geodetic epoch, for each SIRGAS monument, besides the position and secular velocity change of the coordinates, it needs to be specified the episodic deformation due to earthquakes.

\section{Conclusions}

The rupture zone of the 23-June-2001 earthquake falls under the Arequipa upper slope sedimentary basin. The earthquake rupture propagated toward the SE and stopped near the SE gravity and magnetic anomaly highs in the transition zone of the Arequipa-Arica sedimentary basins, offshore Ilo.

The southern Perú coastal region underwent a coseismic subsidence during the 23-June-earthquake, with maximum amplitude in the Camaná region. The Arequipa and Ilo horizontal displacement converge toward the Harvard's epicentroid region. The Camaná and Ilo horizontal displacement vectors converge to a zone near the trench. The Arequipa and Camaná vectors do no intersect.

The pattern of displacement of the June-23-2001 earthquake seems to be bimodal: Rebound and convergence toward the epicentroid in the southeast of Camaná (flow type of motion) and rebound in the northwest. This pattern of displacement is at variance with the coseismic displacement determined for the Nazca-1996 earthquake, which shows rebound and a clockwise rotation pattern.

This paper reports, for the first time, a coseismic displacement of SIRGAS monuments, and points out to the need of resurveying all SIRGAS monuments after the occurrence of moderate or greater earthquakes, to provide reliable information for reduction of topographic and geodetic surveys to the official reference "Epoch".

Acknowledgements. The author would like to thank P. Fabian and two anonymous referees for their constructive comments and suggestions.

Edited by: P. Fabian

Reviewed by: two anonymous referees

\section{References}

Chase Th. E.: Sea floor topography of the central eastern Pacific Ocean. U.S. Department of Interior. U.S. Fish and Wildlife Service. Bureau of Commercial Fisheries. Circular 29, Washington D.C., 1968.

Couch, R. and Whitsett, R. M.: Structure of the Nazca Ridge and the continental shelf and slope of southern Peru, Geol. Soc Ame. Memoir, 154, 569-586, 1981.

Coulbourn, W. T.: Tectonics of the Nazca plate and the continental margin of western South America, $18^{\circ} \mathrm{S}$ to $23^{\circ} \mathrm{S}$, Geol. Soc Ame. Memoir, 154, 587-618, 1981.
Fortes, P., Lauria, E., Brunini, C., Amaya, W., Sánchez, L., Drewes, H., and Seemúller, W.: Current Status and Future Developments of the SIRGAS Project, http://www.ife.uni-hannover.de/ milarbeiter/seeber/seeber_65/pdf_65/fort6.pdf, 2007.

Iwan, W. D. (Ed.): Strong-motion earthquake instrument arrays. Proceedings of the International Workshop on StrongMotion Earthquake Instrument Arrays, 2-5 May 1978, Honolulu, Hawaii, California Institute of Technology, Pasadena California, USA, 103 pp., 1978.

Johnson, S. H. and Ness, G.: Shallow structure of the Perú Margin $12^{\circ} \mathrm{S}-18^{\circ} \mathrm{S}$, Geol. Soc Ame. Memoir, 154, 525-544, 1981.

Koshimura, S. and Sato, H.: 6. Tsunami (PDF 357 kB), http://www. jsceorjp/report/14/02/normal/Peru\%20Ch6.1.pdf, 2005.

Kulm La Verne, D., Dymond, J., Dasch, E. J., Hussong, D. M. (Eds.): Nazca Plate: Crustal Formation and the Andean Convergence, Geol. Soc. Ame. Memoir, 154, 824 pp., 1981.

Macharé, J. and Leureyro, J.: Mapa Neotectonico del Perú (Actualización), Instituto Geofísico del Perú, Lima, Perú, 1991.

Manshinha, L. and Smylie, D.: The displacement field of inclined faults, B. Seismol. Soc. Am., 61(5), 1433-1440, 1971.

NEIC: http://earthquake.usgs.gov/regional/neic, Moment tensor and broadband source parameter search, 2005.

Nishenko, S. P.: Seismic potential for large and great interplate earthquakes along the Chilean and southern Peruvian margins of South America: a quantitative reappraisal, J. Geophys. Res., 90, 3589-3615, 1985.

Norabuena, E., Leffler-Griffin, L., Mao, A., Dixon, T., Stein, S., Sacks, I. S., Ocola, L., and Ellis, M.: Space geodetic observations of Nazca-South America convergence across the central Andes, Science, 279, 358-362, 1998.

Norabuena, E. and Ocola, L.: Desplazamientos Estáticos Asociados al Terremoto de Nazca de Noviembre 12, 1996, www.igp.gob.pe, 2000.

Ocola, L.: Precursory hints of June 23-2001 earthquake in southern Perú seismic gap, American Geophysical Union Fall Meeting, Proceedings, San Francisco, California, USA, 2001.

Ocola, L., Monge, F., Huaco, P., Agüero, C., and Fernández, E.: El terremoto de Nazca de 1996: Intensidades macrosísmicas y efectos geológicos. XII Congreso Peruano de Geología, Resúmenes Extendidos, Sociedad Geológica del Perú, Lima, Perú, 397-400, 2006.

Ruegg, J. C., Olcay, M., and Lazo, D.: Co- post - and Pre(¿)seismic Displacements Associated with the Mw 8.4 Southern Perú Earthquake of 23 June 2001 from Continuous GPS Measurements, Seis. Res. Lett., 72(6), 673-678, 2001.

Song, T.-R. A. and Simmons, M.: Large Trench-Parallel Gravity Variations Predict Seismogenic Behavior in subduction Zones, Science, 301, 630-633, 2003.

Tavera, H., Fernández, E., Bernal, I., Antayhua, Y., Agüero, C., Salas, H., Rodríguez, S., Vilcapoma, L., Zamudio, Y., Portugal, D., Inza, A., Carpio, J., Ccallo, F., and Valdivia, I.: The southern region of Peru earthquake of June 23rd, 2001, J. Seismol., reprint, 2006. 